\title{
Elevated Thalamic Low-Voltage-Activated Currents Precede the Onset of Absence Epilepsy in the SNAP25-Deficient Mouse Mutant Coloboma
}

\author{
Yi Zhang, Alexander P. Vilaythong, Daniel Yoshor, and Jeffrey L. Noebels \\ Developmental Neurogenetics Laboratory, Department of Neurology, Baylor College of Medicine, Houston, Texas 77030
}

\begin{abstract}
Recessive mutations in genes encoding voltage-gated $\mathrm{Ca}^{2+}$ channel subunits alter high-voltage-activated (HVA) calcium currents, impair neurotransmitter release, and stimulate thalamic low-voltage-activated (LVA) currents that contribute to a cortical spike-wave epilepsy phenotype in mice. We now report thalamic LVA current elevations in a non- $\mathrm{Ca}^{2+}$ channel mutant. EEG analysis of Coloboma $(\mathrm{Cm} /+)$, an autosomal dominant mutant mouse lacking one copy of the gene for a synaptosomal-associated protein (SNAP25) that interacts with HVA channels, reveals abnormal spike-wave discharges (SWDs) in the behaving animal. We compared the biophysical properties of both LVA and HVA currents in $\mathrm{Cm} /++$ and wild-type thalamic neurons and observed a $54 \%$ increase in peak current density of LVA currents evoked at $-50 \mathrm{mV}$ from $-110 \mathrm{mV}$ in $\mathrm{Cm} /+$ before the developmental onset of seizures relative to control. The midpoint voltage for steady-state inactivation of LVA currents in $\mathrm{Cm} /+$ was shifted in a depolarized direction by $8 \mathrm{mV}$ before epilepsy onset, and the mean time constant for decay of $\mathrm{LVACa}^{2+}$ currents at $-50 \mathrm{mV}$ was also prolonged. No significant differences were found in recovery

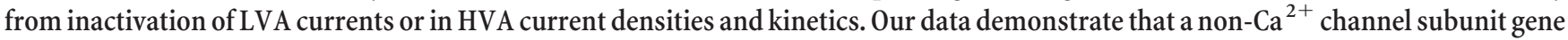
mutation leads to potentiated thalamic LVA currents that precede the appearance of SWDs and that altered somatodendritic HVA currents are not required for abnormal thalamocortical oscillations. We suggest that presynaptic release defects shared by these mutants lead to postsynaptic LVA excitability increases in thalamic pacemaker neurons that favor rebound bursting and absence epilepsy.
\end{abstract}

Key words: T-type calcium channels; thalamocortical relay cells; calcium channelopathy; stargazer; tottering; lethargic

\section{Introduction}

$\mathrm{Ca}^{2+}$ currents, especially the low-voltage-activated (LVA) currents within thalamic circuitry, play a critical role in the development of thalamocortical network oscillations underlying absence epilepsy (Huguenard, 1996; McCormick and Contreras, 2001; Crunelli and Leresche, 2002). Mutant alleles of high-voltageactivated (HVA) subunit genes $\mathrm{Ca}_{\mathrm{v}} 2.1 / \alpha_{1 \mathrm{~A}}$ (tottering/tg; leaner/ $\operatorname{tg}^{l a}$; rocker $\left./ \mathrm{tg}^{r k r}\right), \beta_{4}$ (lethargic/lh), $\gamma 2$ (stargazer/stg), and $\alpha 2 \delta 2$ $(d u c k y / d u)$ have been associated with cortical spike-wave discharges (SWDs) in mice resembling those in human idiopathic generalized absence epilepsy (Noebels, 1984; Noebels et al., 1990; Fletcher et al., 1996; Burgess et al., 1997; Letts et al., 1998; Barclay et al., 2001; Zwingman et al., 2001). Human $\alpha 1$ A mutations associated with SWDs have also been described (Jouvenceau et al., 2001). Several of these mutations have been shown to alter membrane excitability and impair presynaptic neurotransmitter release by reducing P/Q-type $\mathrm{Ca}^{2+}$ currents (Dove et al., 1998; Wakamori et al., 1998; Qian and Noebels, 2000).

Although it was initially unclear how decreased P/Q $\mathrm{Ca}^{2+}$

Received March 17, 2004; revised April 20, 2004; accepted April 21, 2004.

This work was supported by National Institute of Neurological Disorders and Stroke Grant NS29709 (J.L.N.) and the Blue Bird Circle Foundation.

Correspondence should be addressed to Dr. Jeffrey L. Noebels, Department of Neurology, Baylor College of Medicine, One Baylor Plaza, Houston, TX 77030. E-mail: jnoebels@bcm.tmc.edu.

DOI:10.1523/JNEUROSCI.0992-04.2004

Copyright $\odot 2004$ Society for Neuroscience $\quad$ 0270-6474/04/245239-10\$15.00/0 current could lead to membrane hyperexcitability and seizures, recent analysis of thalamic neurons in $t g$, $\mathrm{lh}$, and stg mutants reveals not only altered HVA current densities and kinetics, but striking increases in LVA peak currents and channel availability (Zhang et al., 2002). The elevated thalamic LVA currents provide a common downstream excitability defect that favors seizure generation by promoting rebound bursting. The molecular link between the mutated channel subunit and the potentiated LVA current is unclear. There is no evidence that $\alpha 1 \mathrm{~A}, \beta 4$, or $\gamma 2$ subunits directly interact with the $\alpha 1 \mathrm{G}-\mathrm{I}$ subunits that mediate thalamic LVA currents. Furthermore, no increases in $\alpha 1 \mathrm{G}-\mathrm{I}$ mRNA expression or altered modulation of LVA currents were found. One possibility remaining to be explored is whether the LVA potentiation specifically depends on impaired calcium entry through the mutant P/Q-type channels or whether it can arise independently of the primary calcium channelopathy. A second is whether LVA increases might be induced by seizures themselves.

The neurological mouse mutant Coloboma $(\mathrm{Cm} /+$; homozygous lethal) is an autosomal dominant mutation showing hyperactivity and learning deficits that maps to a small deleted region on chromosome 2 (Hess et al., 1992, 1994). The Coloboma locus spans the target membrane receptor (t-SNARE) gene encoding soluble $\mathrm{N}$-ethyl-maleimide-sensitive factor attachment protein (SNAP25), a core complex protein that interacts with $\mathrm{Ca}^{2+}$ channel $\alpha$ subunits and participates in $\mathrm{Ca}^{2+}$-dependent neurotransmitter exocytosis (Rettig et al., 1996; Washbourne et al., 2002; Sorensen et 
al., 2003). Haploinsufficency of the SNAP25 gene in $\mathrm{Cm} /+$ mice reduces $50 \%$ of the SNAP2 5 mRNA and protein content in brain and impairs evoked neurotransmitter release (Raber et al., 1997; Wilson, 2000). No genes for voltage-gated ion channels are contained within or flank this region, and the neurobehavioral phenotype is rescued by SNAP25 transgene expression (Hess et al., 1996). On the basis of the functional overlap of altered transmitter release shared with the $\mathrm{Ca}^{2+}$ channelopathy models, we examined $\mathrm{Cm} /+$ mice for abnormal cortical synchronization and thalamic excitability changes. We discovered that $\mathrm{Cm} /+$ mice show robust cortical SWDs and thalamic T-type current increases closely resembling those described in $\mathrm{Ca}^{2+}$ channel mutants. In addition, the T-type current increases clearly precede the developmental onset of cortical discharges.

\section{Materials and Methods}

\section{Chronic electroencephalographic recordings}

$\mathrm{Cm} /+$ mice and their wild-type littermates $(\mathrm{C} 3 \mathrm{H} / \mathrm{HESNJ})$ from the age of postnatal day $(\mathrm{P})$ 10-30 were implanted for chronic EEG recordings as described previously (Qiao and Noebels, 1993). Mice were anesthetized with Avertin (1.25\% tribromoethanol/amyl alcohol solution, i.p.) using a dose of $0.02 \mathrm{ml} / \mathrm{gm}$. Teflon-coated silver wire electrodes $(0.005$ inch diameter) soldered to a microminiature connector were implanted bilaterally into the subdural space over frontal and parietal cortices. Digital EEG activity was recorded daily during random $2 \mathrm{hr}$ samples (Stellate Systems; Harmonie software version 5.0b). A digital video camera was used to simultaneously monitor behavior during the EEG recording periods. All recordings were performed at least $24 \mathrm{hr}$ after surgery on mice moving freely in the test cage. After the recordings, the EEG and digital video from mice were analyzed for the incidence and duration of spontaneous cortical spike activity. Abnormal synchronous discharges with a minimum amplitude of twice the background EEG voltage and a minimum duration of $1 \mathrm{sec}$ were included for analysis, and spike bursts separated by $<1 \mathrm{sec}$ were counted as a single discharge. To developmentally compare the EEG results of $\mathrm{Cm} /+$ with those from $\mathrm{tg}$ and $\mathrm{stg}$ mutants, similar recordings were conducted in tottering (C57BL/6J-Cacna1 $a^{\text {tg/tg }}$ ), stargazer (C57BL/6J-Cacn $2^{\text {stg/stg }}$ ), and their wild-type control (C57BL/ $6 \mathrm{~J},+/+)$ mice over a similar age range.

\section{Preparation of brain slices}

Coronal brain slices (350 $\mu \mathrm{m}$ thick) were prepared from P13-16 heterozygous Coloboma (C3H/HESNJ, $\mathrm{Cm} /+$ ) and homozygous wild-type $(\mathrm{C} 3 \mathrm{H} / \mathrm{HESNJ},+/+)$ littermate mice. Slices were obtained at the level of the lateral dorsal nucleus (LDN) of the thalamus as described previously (Zhang et al., 2002). Tissue was sectioned by vibratome in a solution containing (in mM): 125 choline-Cl, $3.0 \mathrm{KCl}, 1.25 \mathrm{NaH}_{2} \mathrm{PO}_{4}, 25$ $\mathrm{NaHCO}_{3}, 1.0 \mathrm{CaCl}_{2}, 7.0 \mathrm{MgCl}_{2}, 10$ dextrose, 1.3 ascorbate acid, and 3.0 pyruvate, bubbled with $95 \% \mathrm{O}_{2}-5 \% \mathrm{CO}_{2}$ (at $4^{\circ} \mathrm{C}$ ) (Kapur et al., 1998). Slices were then incubated in an artificial CSF solution for $40 \mathrm{~min}$ at $37^{\circ} \mathrm{C}$ and then maintained at room temperature $\left(22-25^{\circ} \mathrm{C}\right)$. The artificial CSF was gassed with $95 \% \mathrm{O}_{2}-5 \% \mathrm{CO}_{2}$ and contained (in $\mathrm{mM}$ ): $130 \mathrm{NaCl}, 3.0$ $\mathrm{KCl}, 2.0 \mathrm{MgCl}_{2}, 2.0 \mathrm{CaCl}_{2}, 1.25 \mathrm{NaH}_{2} \mathrm{PO}_{4}, 26 \mathrm{NaHCO}_{3}$, and 10 glucose.

\section{Electrophysiological recording}

Macroscopic $\mathrm{Ca}^{2+}$ currents from thalamocortical (TC) cells in LDN were recorded using the whole-cell configuration of the patch-clamp technique. An upright microscope (Axioskop, Zeiss Instruments) fitted with a $40 \times$ water-immersion objective and differential interference contrast optics was used to view the slices and identify neurons for analysis. Voltage command pulses were generated by a computer using pCLAMP 8.02 software. Currents were recorded with an Axopatch-1D amplifier, filtered at $10 \mathrm{kHz}(-3 \mathrm{~dB})$, and compensated for series resistance $(\sim 70 \%)$. Patch electrodes were drawn from borosilicate glass and coated with Sylgard. $\mathrm{Ca}^{2+}$ currents were corrected for leak and capacitive currents by subtracting a scaled current elicited by a $10 \mathrm{mV}$ hyperpolarization from the standard holding potential of $-70 \mathrm{mV}$. All recordings were performed at room temperature $\left(22-25^{\circ} \mathrm{C}\right)$.

Solutions. The recording bath solution consisted of (in $\mathrm{mm}$ ): $115 \mathrm{NaCl}$,
$3.0 \mathrm{KCl}, 10$ sucrose, 10 glucose, $26 \mathrm{NaHCO}_{3}, 2 \mathrm{MgCl}_{2}, 2.5 \mathrm{CaCl}_{2}, 0.5$ 4-aminopyridine, $5 \mathrm{CsCl}, 10 \mathrm{TEA}-\mathrm{Cl}$, and $0.001 \mathrm{TTX}, \mathrm{pH} 7.4$ (gassed with $95 \% \mathrm{O}_{2}$ and $5 \% \mathrm{CO}_{2}$ ). The intracellular pipette solution contained (in mM): 78 Cs-gluconate, 20 HEPES, 10 BAPTA-Cs4 (cell impermeant), $0.5 \mathrm{CaCl}_{2}, 1.0 \mathrm{MgCl}_{2}, 4 \mathrm{Mg}$-ATP, $0.3 \mathrm{GTP}$-Tris, 6 phosphocreatine (DiTris salt), $4.0 \mathrm{NaCl}$, and 20 TEA-Cl, pH 7.3 (titrated with $\mathrm{CsOH}$ ).

Voltage protocols. To generate $\mathrm{Ca}^{2+}$ channel current-voltage $(I-V)$ curves, currents were elicited by applying voltage step commands (200 $\mathrm{msec}$ ) to varying potentials from a $3 \mathrm{sec}$ prepulse potential at -60 or $-110 \mathrm{mV}$. The $I-V$ protocol for $\mathrm{HVA} \mathrm{Ca}^{2+}$ currents consisted of voltage steps from -80 to $+60 \mathrm{mV}$ in $5 \mathrm{mV}$ increments triggered from a $3 \mathrm{sec}$ prepulse potential at $-60 \mathrm{mV}$. To define LVA Ca ${ }^{2+}$ currents, difference currents obtained by digital subtraction of the currents elicited during depolarizing voltage steps from -60 and $-110 \mathrm{mV}$ were used. Standard voltage protocols for steady-state activation (SSA) of $\mathrm{HVA} \mathrm{Ca}^{2+}$ currents, as well as the steady-state inactivation (SSI) and recovery from inactivation (RFI) of LVA currents, respectively, were applied and are explained in further detail in the Figure legends. In our study, we did not find any significant time-dependent $\mathrm{ICa}^{2+}$ rundown within $40 \mathrm{~min}$ after membrane rupture, and all data included in this study were obtained within this time interval. Statistical data analysis was performed using the Student's $t$ test or one-way ANOVA with the post hoc test. Differences where $p<0.05$ were accepted as statistically significant. The data shown represent means $\pm \mathrm{SE}$.

\section{Results \\ Cortical spike-wave discharges in the $\mathrm{Cm} /+$ mutant are associated with elevated $\mathrm{LVA} \mathrm{Ca}{ }^{2+}$ currents in thalamic neurons}

Similar to mice with recessive mutations in calcium channel subunit genes, we observed frequent spontaneous bursts of $5-6 \mathrm{~Hz}$ bilateral cortical SWDs in all $\mathrm{Cm} /+$ mutants. These stereotyped discharges appeared in the awake animal and were always accompanied by simultaneous behavioral arrest. Representative bilateral EEG traces recorded in adult $\mathrm{Cm} /+$ mice are shown in Figure $1 A$ (top). Intraperitoneal injection of $5 \mathrm{mmol} / \mathrm{kg}$ ethosuximide (ETX) completely blocked SWDs within 2-4 min (Fig. 1 A, middle). The mean number of SWDs in adult $\mathrm{Cm} /+$ mice was reduced from $29.3 \pm 4.2$ per hour before injection to 0 per hour for 2-4 hr after injection (Fig. $1 \mathrm{~A}$, bottom), followed by full recovery of the SWDs and absence-type seizures. The sensitivity of intraperitoneal injection of ETX in $\mathrm{Cm} /+$ mutants was reduced significantly compared with the effective doses used in mice absence models: $t g$, lh, and stg models (1-1.4 mmol/kg) (Heller et al., 1983; Aizawa et al., 1997). Spike wave discharges of this general pattern and behavioral phenotype are seen in human absence epilepsy and $\mathrm{Ca}^{2+}$ channel mouse mutants (Noebels and Sidman, 1979; Hosford et al., 1992; Qiao and Noebels, 1993), as well as in other genetic models of absence in rat (Marescaux et al., 1992; Coenen and Van Luijtelaar, 2003).

We then analyzed low-voltage-activated $\mathrm{Ca}^{2+}$ current amplitudes and kinetics in TC neurons to determine whether any alterations coexist with the expression of absence epilepsy in the $\mathrm{Cm} /+$ mutant. In Figure $1 \mathrm{~B}$, the top panel shows representative traces of $\mathrm{LVA} \mathrm{Ca}^{2+}$ currents in response to a test pulse to -50 $\mathrm{mV}$ arising from a $3 \mathrm{sec}$ prepulse to $-110 \mathrm{mV}$ in TC neurons from wild-type and $\mathrm{Cm} /+$ mice. At a membrane potential of -50 $\mathrm{mV}$, all LVA $\mathrm{Ca}^{2+}$ currents have recovered from inactivation and are thus available for opening in both wild-type and mutant neurons (see Figs. $4 B, 5 B$ ), whereas HVA Ca ${ }^{2+}$ currents in these cells have not yet started to activate (see Fig. $6 B$ ). The current traces of the LVA calcium channels show fast activation and inactivation, similar to that found in vitro by expression of $\mathrm{Ca}_{\mathrm{v}} 3.1\left(\alpha_{1 \mathrm{G}}\right)$ and $\mathrm{Ca}_{\mathrm{v}} 3.2\left(\alpha_{1 \mathrm{H}}\right)$ T-type calcium channels (Lee et al., 1999; Delisle and Satin, 2000; Zhang et al., 2000) as well as native LVA currents 
A

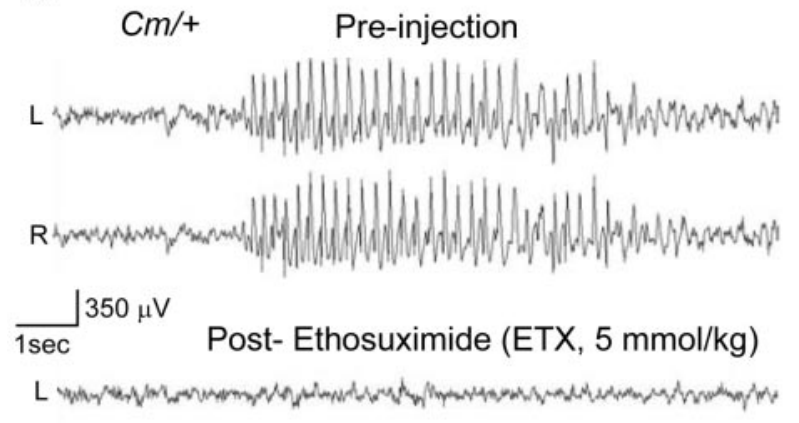



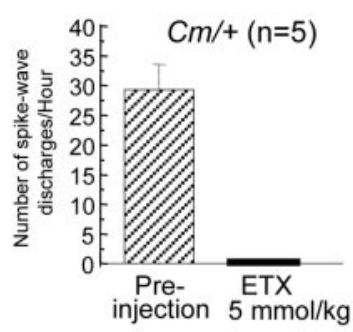

B
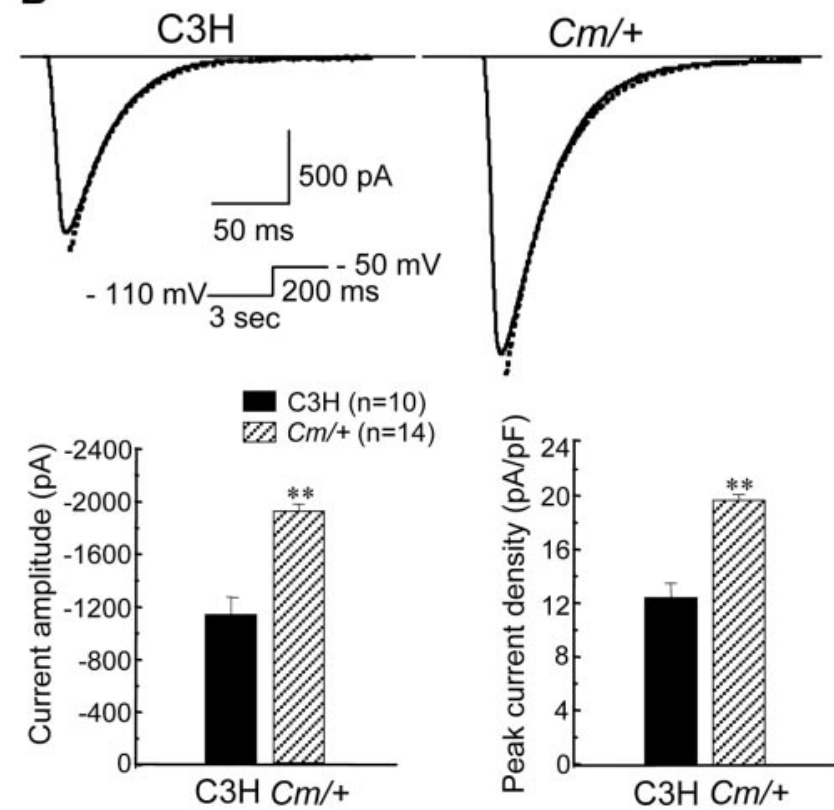

Figure 1. Spike-wave discharges coexist with elevated low-voltage-activated $\mathrm{Ca}^{2+}$ peak current in thalamic neurons of Coloboma mutant mice. $A$, Representative bilateral EEG traces showing $5 \sim 6 \mathrm{~Hz}$ spike-wave discharges (top) and pharmacological sensitivity to $5 \mathrm{mmol} / \mathrm{kg}$ ethosuximide (ETX, i.p.) in $\mathrm{Cm} /+$ mutants $(n=5$; at P30) (middle). L and R designate left and right frontal cortex recording sites. The bottom panel shows the mean incidence of spike-wave discharges in $\mathrm{Cm} /+$ mutant mice before and after ETX injection. $B$, Increased thalamic $\mathrm{LVACC}^{2+}$ peak current in Coloboma. Top panel, Representative LVA current traces from thalamocortical relay cells (TCS) of the $\mathrm{LDN}$ in control (C3H) and $\mathrm{Cm} /+$ mice at age P15. The cell capacitance values of the two neurons were 100 and $101 \mathrm{pF}$ in $\mathrm{C} 3 \mathrm{H}$ and $\mathrm{Cm} /+$, respectively; holding potential $=-70 \mathrm{mV}$. The membrane potential was prepulsed to $-110 \mathrm{mV}$ for 3 sec before stepping to $-50 \mathrm{mV}$ for $200 \mathrm{msec}$. Decay of the current was fitted by a single-exponential function (superimposed dotted line). A significant alteration in the macroscopic current decay was found in $\mathrm{Cm} /+$ neurons. The time constants $(\tau)$ for decay of the representative currents are $24.6 \mathrm{msec}$ in $\mathrm{C} 3 \mathrm{H}$ and $29.8 \mathrm{msec}$ in $\mathrm{Cm} /+$, respectively. Bottom panel, Elevated $\mathrm{LVACa}^{2+}$ current amplitude and peak current density from $\mathrm{Cm} /+\mathrm{TC}$. LVA currents were evoked at the same membrane potential as described in top panel. ${ }^{* *} p<0.001$ versus control at corresponding age. from dissociated rat TC neurons (Destexhe et al., 1998) and TC neurons of $t g, l h$, and $s t g$ brain slices (Zhang et al., 2002). The peak current densities (normalized by cell capacitance) of LVA currents at a membrane potential of $-50 \mathrm{mV}$ were increased by $60 \%$ compared with the corresponding value in control neurons at this age (P14-16) (Fig. $1 B$, right bottom panel). The mean peak current amplitudes and peak current densities were $-1142.3 \pm$ $131.9(\mathrm{pA})$ and $12.4 \pm 1.1(\mathrm{pA} / \mathrm{pF})$ in control mice and $-1916.2 \pm 54.3^{* *}(\mathrm{pA})$ and $19.8 \pm 0.4^{* *}(\mathrm{pA} / \mathrm{pF})$ in $C m /+$ $\left({ }^{* *} p<0.001\right.$ vs control).

\section{Age of onset and mean incidence of spontaneous cortical SWDs in $\mathrm{Cm} /+$ mutants}

The onset of cortical SWDs in $\mathrm{Cm} /+$ mice, like those in mice bearing $\mathrm{Ca}^{2+}$ channelopathies, displayed a highly reproducible developmental profile. Representative bilateral EEG traces of both $\mathrm{Cm} /+$ mutants and $\mathrm{C} 3 \mathrm{H}$ control mice recorded at various postnatal ages from P13 through adulthood are shown in Figure $2 \mathrm{~A}$ and are compared with EEG traces at the same ages from $t g$ and stg mutants as well as their control genotypes. In our study, no synchronous discharges were ever recorded from $\mathrm{Cm} /+\mathrm{mu}-$ tants at ages P11-13. SWDs emerged at P14-15 and were always present by $\mathrm{P} 20$ in $\mathrm{Cm} /+$ mice. As shown in Figure $2 \mathrm{~A}$, most of the spike-wave discharges in the immature (P14-18) $\mathrm{Cm} /+$ mouse brain display a pattern of prolonged and frequent $3-4 \mathrm{~Hz}$ synchronous discharges, intermixed with occasional shorter $5-6 \mathrm{~Hz}$ bursts. From P20 onward, a 5-6 Hz spike-wave pattern becomes the predominant pattern in $\mathrm{Cm} /+$ mutants. In comparison, cortical SWDs were also first visible at P13 and P14, respectively, in stg and $t g$ mutants. Similar to $\mathrm{Cm} /+$, SWDs exhibited a variable spike frequency pattern of $3 \sim 6 \mathrm{~Hz}$ during the period from $\mathrm{P} 13$ to P18 and then stabilized at 5-6 Hz from P20 onward in both $t g$ and $s t g$ mice. No SWDs were ever observed in $\mathrm{C} 3 \mathrm{H}$ (wild-type littermates of $\mathrm{Cm} /+)$ and C57/BL6 $(+/+$ control for $t g$ and stg) mice within the age range of P11 to P25. Group data showing the mean incidence of cortical discharges in $\mathrm{Cm} /+$ mutants and $\mathrm{C} 3 \mathrm{H}+/+$ control mice during development are demonstrated in Figure $2 B$. As shown, the onset of synchronous cortical discharges began with rare bursts (1-30 sec duration; some as long as 150-300 sec) in $\mathrm{Cm} /+$ mutant mice at the age of P14 and P15 (two to five bursts per hour) and gradually increased to a stable rate exceeding 20 per hour. The mean incidence of spike-wave discharges in $\mathrm{Cm} /+$ mice at $\mathrm{P} 20$ was $\sim 15$ bursts per hour and then reached 25-45 bursts per hour between P21 and P25. Behavioral video image data obtained simultaneously with EEG recordings showed that except for very brief duration discharges, the SWDs were seen when $\mathrm{Cm} /+$ mutants were motionless in a state of quiet wakefulness, similar to the correlation with behavioral arrest in other absence seizure models. The patterns of onset and incidence of spike-wave discharges in $\mathrm{Cm} /+$ mutants are essentially identical to those exhibited in $\mathrm{Ca}^{2+}$ channel mutants (Noebels and Sidman, 1979; Noebels, 1984; Noebels et al., 1990). No synchronous discharges were ever recorded in adolescent $\mathrm{C} 3 \mathrm{H}$ control mice; however, rare isolated SWDs were noted in recordings from some $+/+\mathrm{C} 3 \mathrm{H}$ aged $\geq 5$ weeks, suggesting that this genetic background may express additional permissive susceptibility genes for this trait.

The increased peak current density and prolonged current decay of thalamic LVA calcium currents precede seizure onset We examined thalamic LVA calcium currents in brain slices obtained at age P13, at least $24 \mathrm{hr}$ and typically several days before the earliest evidence of cortical SWDs in $\mathrm{Cm} /+$ mutants. The 
data collected at P13 are compared with those obtained at P14-16 when seizures began to emerge. Figure $3 A$ shows representative traces of $\mathrm{LVA} \mathrm{Ca}^{2+}$ currents in response to a test pulse to $-50 \mathrm{mV}$ from a $3 \mathrm{sec}$ prepulse to $-110 \mathrm{mV}$ in TC neurons from wild-type and $\mathrm{Cm} /+$ mice. The current traces of the LVA calcium channels at both P13 (before the onset of SWDs) and P15 (after the emergence of SWDs) display fast activation and inactivation kinetics as well as activation at low voltages, which together define the characteristic properties of T-type $\mathrm{Ca}^{2+}$ channels (Destexhe et al., 1998; Lee et al., 1999; Zhang et al., 2000, 2002). The peak current densities of LVA currents at a membrane potential of $-50 \mathrm{mV}$ increased by $54 \%$ in $\mathrm{Cm} /+$ at $\mathrm{P} 13$ and $60 \%$ in $\mathrm{Cm} /+$ at P14-16 compared with corresponding values in control $+/+$ neurons at same age (Fig. $3 B$ ). The mean peak current amplitude and peak current density were $-1418.0 \pm 132.9(\mathrm{pA})$ and $12.7 \pm 0.5(\mathrm{pA} / \mathrm{pF})$ in control and $-2015.8 \pm 117.9^{\star}(\mathrm{pA})$ and $19.5 \pm 1.2^{\star *}$ $(\mathrm{pA} / \mathrm{pF})$ in $\mathrm{Cm} /+$ at age $\mathrm{P} 13,-1142.3 \pm$ $131.9(\mathrm{pA})$ and $12.4 \pm 1.1(\mathrm{pA} / \mathrm{pF})$ in control, and $-1916.2 \pm 54.3^{\star *}(\mathrm{pA})$ and $19.8 \pm 0.4^{* *}(\mathrm{pA} / \mathrm{pF})$ in $C \mathrm{~m} /+$ aged P14-16 ${ }^{* *} p<0.001 ;{ }^{\star} p<0.01$ vs control). The amplitude and peak current density of control and $\mathrm{Cm} /+$ at P13 were not significantly different from corresponding data at $\mathrm{P} 14-16$, respectively. Because synchronous discharges in $\mathrm{Cm} /+$ mutant mice are never seen until P14-16 (Fig. 2B), this result demonstrates that thalamic LVA $\mathrm{Ca}^{2+}$ currents are elevated before the onset of discharges and therefore are not induced by the seizure itself.

The duration of macroscopic inactivation of LVA $\mathrm{Ca}^{2+}$ currents in both control and mutant mice is closer to the time scale observed in $\mathrm{Ca}_{\mathrm{v}} 3.1$ but not $\mathrm{Ca}_{\mathrm{v}} 3.2 \mathrm{~T}$-type calcium channels expressed in mammalian cells (Lee et al., 1999; Zhang et al., 2000). The decay of macroscopic LVA currents evoked at $-50 \mathrm{mV}$ was fitted by a single-exponential function (Fig. 3A); however, unlike what we observed in $t g$, $l h$, and stg neurons, we found significant prolongation of the time constant for decay of macroscopic LVA currents in $\mathrm{Cm} /+\left(28.1 \pm 0.69^{* *}\right.$ msec; P13-16) compared with that in wild-type neurons at the same age range $\left(23.6 \pm 0.86 \mathrm{msec} ;{ }^{\star *} p<0.001\right)$. We here combined data derived from mice at P13 and at ages ranging from P14 to P16 in both the control group and the $\mathrm{Cm} /+$ group, because the $\tau$ for decay at P13 is not significantly different from that at P14-16 in either control or mutant mice.

Depolarizing shifts in voltage dependence of steady-state inactivation and unaltered kinetics for recovery from inactivation of LVA currents in $\mathrm{Cm} /+$ mice

We next examined the voltage-dependent inactivation and recovery from inactivation of LVA $\mathrm{Ca}^{2+}$ currents in both wild-type

P13 L

20

P13 L

B $\begin{array}{llll}\text { A } & \mathrm{Cm} /+ & \mathrm{tg} / \mathrm{tg} & \mathrm{stg} / \mathrm{stg}\end{array}$

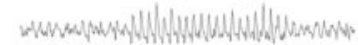

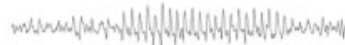




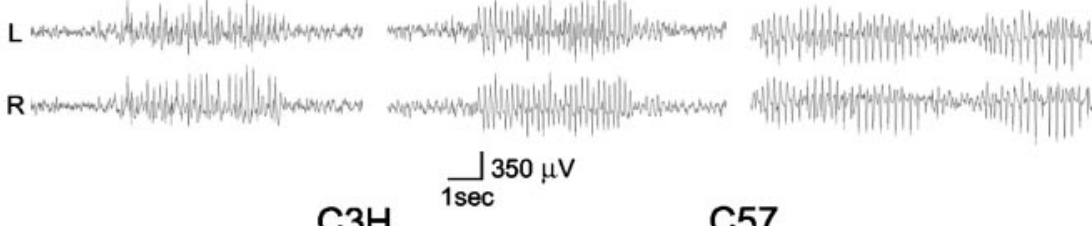

C3H

C57
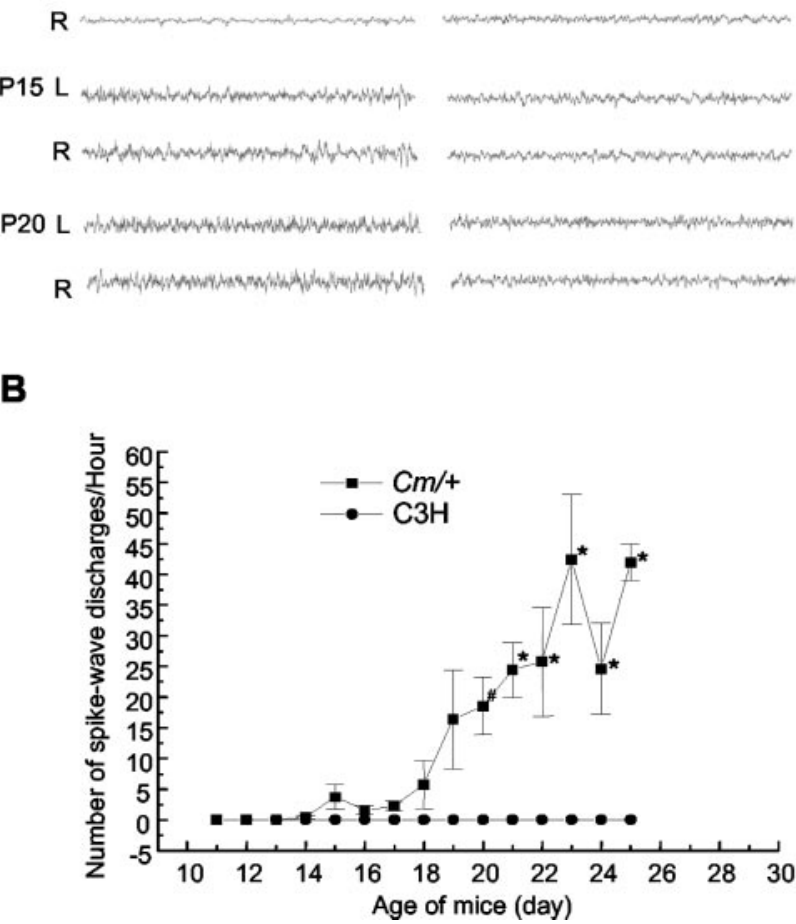

Figure 2. Onset and mean incidence of spike-wave discharges in $\mathrm{Cm} /+$ mutant mice during development. $A$, Representative bilateral EEG traces recorded in $\mathrm{Cm} /+$, compared with those in $\mathrm{tg}$ and stg mutants at the same age. B, Group data showing the P25. In C3H ( $n=8)$, no SWDs were ever observed throughout the recording period. For $\mathrm{Cm} /+$ mice, each age point includes mean data from two to seven mice $\pm S E$; ${ }^{\#} p<0.01 ;{ }^{*} p<0.001$ versus corresponding values of $C m /+$ at $P 14-17$, respectively.

and $\mathrm{Cm} /+$ neurons. The current traces of SSI of LVA are shown in Figure $4 A$. For the SSI protocol, we used a 4 sec prepulse to various membrane potentials before delivering a second test stimulus to $-50 \mathrm{mV}$. The $4 \mathrm{sec}$ prepulse was long enough to bring channels to a steady-state condition, because all $\mathrm{LVA} \mathrm{Ca}^{2+}$ channels in TC neurons recover from inactivation within $3 \mathrm{sec}$ (Fig. $5 B$ ). As demonstrated in Figure $4 A$, LVA currents elicited at -50 $\mathrm{mV}$ from different premembrane potentials in both control and $\mathrm{Cm} /+$ mutant show fast inactivation and decay completely within $200 \mathrm{msec}$. We found a significant depolarizing shift of the steady-state inactivation curves of LVA currents in the mutant both before the onset of seizure (P13) and after seizure generation (P14-16) in contrast to wild-type neurons (Fig. 4B). The mean half-maximal voltages $\left(V_{1 / 2}\right)$ for SSI curves were $-84.0 \pm 0.7 \mathrm{mV}$ in control $(\mathrm{P} 13-16),-76.0 \pm 2.1^{*} \mathrm{mV}$ in $\mathrm{Cm} /+$ at P13, $-75.5 \pm$ 
A
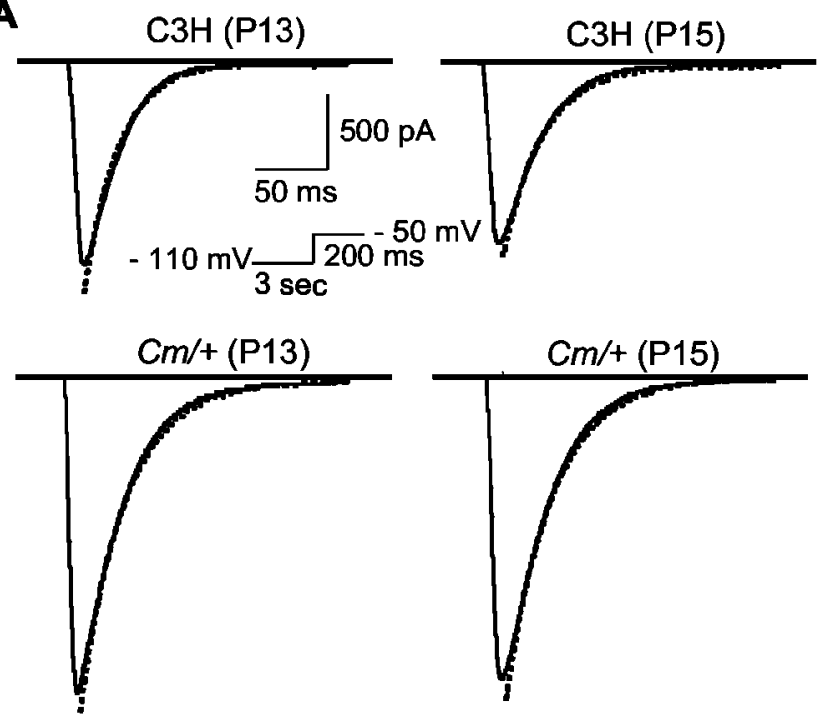

B

P13; $\mathrm{C} 3 \mathrm{H}(\mathrm{n}=6), \mathrm{Cm} /+(\mathrm{n}=8)$

CL14-16; C3H $(n=10), C m /+(n=14)$
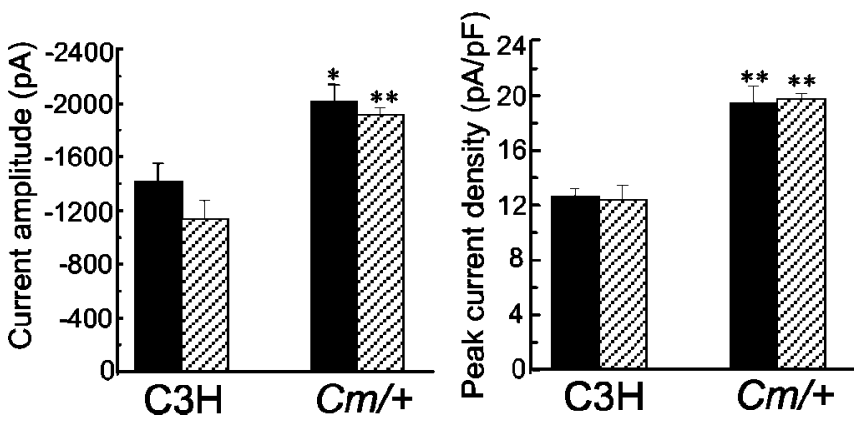

Figure 3. Increased low-voltage-activated $\mathrm{Ca}^{2+}$ peak current in Coloboma. A, Representative LVA current traces from thalamocortical relay cells $(\mathrm{TCS})$ in control $(\mathrm{C} 3 \mathrm{H})$ and $\mathrm{Cm} /+$ mice at ages P13 and P15. The cell capacitance values of these neurons were 104 and $105 \mathrm{pF} \mathrm{in} \mathrm{C} 3 \mathrm{H}$ and $\mathrm{Cm} /+$ at $\mathrm{P} 13$, and 100 and $101 \mathrm{pF}$ in $\mathrm{C} 3 \mathrm{H}$ and $\mathrm{Cm} /+$ at $\mathrm{P} 15$, respectively. The holding potential and voltage protocol used were the same as described in Figure $1 B$. Decay of the current was fitted by a single-exponential function (superimposed dotted line). A significant alteration in macroscopic current decay was found in $\mathrm{Cm} /+$. The time constants $\tau$ for decay of representative current traces at P13 and P15 are 22.53 and $24.6 \mathrm{msec}$ in $\mathrm{C} 3 \mathrm{H}$ and 29.4 and $29.8 \mathrm{msec}$ in $\mathrm{Cm} /+$, respectively. $B$, Elevated $\mathrm{LVACa}^{2+}$ current amplitude and peak current density from $\mathrm{Cm} /+\mathrm{TC}$ neurons. LVA currents were evoked at the same membrane potential as described in $A .{ }^{* *} p<0.001 ;{ }^{*} p<0.01$ versus control at corresponding age.

$3.1{ }^{\#} \mathrm{mV}$ in $\mathrm{Cm} /+$ at $\mathrm{P} 14-16$, respectively $\left({ }^{*} p<0.01 ;{ }^{\#} p<0.05\right.$ vs control). The $8-8.5 \mathrm{mV}$ depolarizing shifts of the voltage dependence for SSI of LVA currents in TC neurons of $\mathrm{Cm} /+$ mice suggest that at physiological membrane potentials varying from -70 to $-75 \mathrm{mV}$, a higher fraction of all LVA calcium channels is available for opening in the mutant relative to control mice. As seen for the LVA peak current density in $\mathrm{Cm} /+$ (Fig. 4), the $V_{1 / 2}$ for SSI in mutant mice also shifted significantly in a depolarizing direction at P13, a time preceding the onset of SWDs (Fig. $2 \mathrm{~B}$ ). This depolarized shift of $V_{1 / 2}$ for SSI of LVA currents remained after seizure onset (Fig. $4 B$ ). Accordingly, in parallel with an increased current density (Fig. 3), the depolarizing shift of $V_{1 / 2}$ for SSI of LVA currents in $\mathrm{Cm} /+$ also preceded the emergence of SWDs. The depolarizing shift of the SSI curve for LVA currents in $\mathrm{Cm} /+$ is consistent with our previous data showing 7.5-13.5 mV depolarizing shifts of SSI for thalamic LVA currents in $t g, l h$, and
A
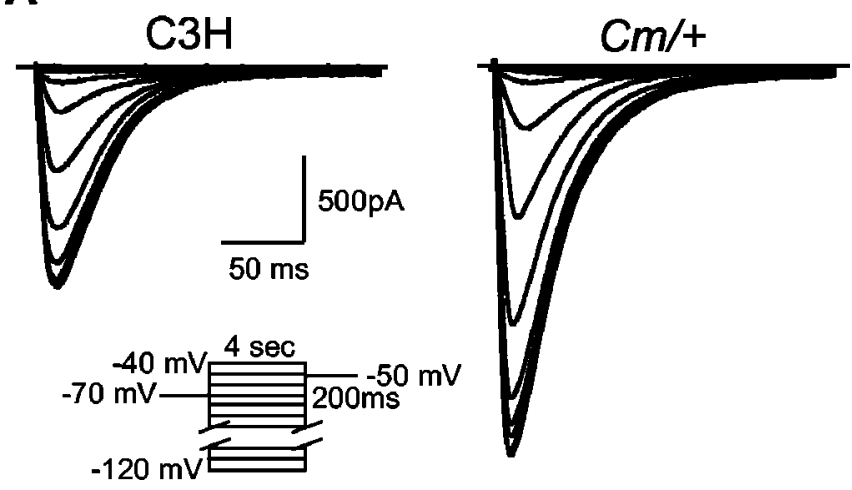

B

$\underline{\text { SSI }}$



Figure 4. Depolarized shift of the voltage dependence of low-voltage-activated calcium channel availability (steady-state inactivation) in Coloboma mutants. $A$, Representative current traces for SSI of LVA Ca ${ }^{2+}$ currents. A standard double-pulse protocol for steady-state inactivation was given from the holding potential of $-70 \mathrm{mV}$. A 4 sec prepulse at potentials ranging from -120 to $-40 \mathrm{mV}$ preceded each depolarization, followed by a subsequent voltage step to $-50 \mathrm{mV}$ for $200 \mathrm{msec}$. The interpulse interval was $10 \mathrm{sec}$. B, Normalized current-voltage curves for SSI of $\mathrm{LVACa}^{2+}$ currents. Current amplitude from the inactivation protocol, normalized to maximum, was plotted as a function of prepulse membrane potentials and best fitted with a Boltzmann function: $I / I_{\max }=\left\{1+\exp \left(V-V_{1 / 2}\right) / k\right\}-1$.

stg mutants (Zhang et al., 2002). This shift in the voltage dependence of SSI of LVA currents to a more depolarized level in $\mathrm{Cm} /+$ mice will increase membrane excitability and therefore provide an additional biophysical mechanism that may contribute to neuronal burst synchronization in $\mathrm{Cm} /+$ mutants.

Figure $5 A$ displays raw current traces of the RFI of thalamic LVA Ca ${ }^{2+}$ currents in control and $\mathrm{Cm} /+$ mice. As shown, RFI in both control and mutant cells was complete within $3 \mathrm{sec}$ (Fig. 5B). The recovery from inactivation curve was best fitted with a twoexponential function, and the fast and slow time constants derived from curve fitting did not significantly differ in $\mathrm{Cm} /+$ when compared with control mice, either before or after the onset of SWDs. The values of the fast time constant $\left(\tau_{1}\right)$ were 260 and 240 msec for control and $\mathrm{Cm} /+$ at P13 and 250 and $210 \mathrm{msec}$ for control and $\mathrm{Cm} /+$ at $\mathrm{P} 14-16$, respectively. The values of slow 
A

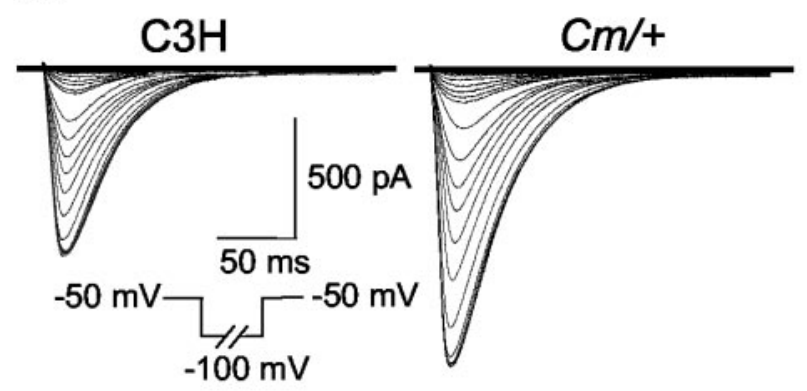

B

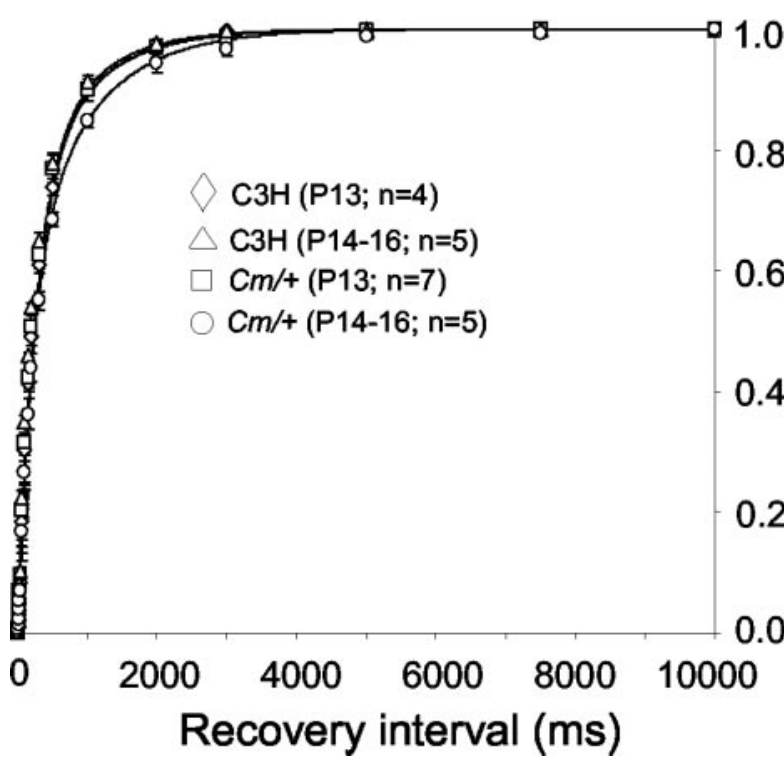

Figure 5. Recovery from inactivation of $L V A C a^{2+}$ currents. $A$, Representative current traces for recovery from inactivation of LVA currents in control and $\mathrm{Cm} /+$. The holding potential was set to $-50 \mathrm{mV}$, and $50 \mathrm{mV}$ hyperpolarizations of incremental duration were applied. LVA peak amplitude was measured after returning to $-50 \mathrm{mV}$. $B$, Recovery from inactivation curves. Recovery curves were established by plotting the normalized peak amplitude versus duration. The recovery curves followed a two-exponential time course, and the fast time constant $\left(\tau_{1}\right)$ and slow time constant $\left(\tau_{2}\right)$ were derived from curve fitting.

time constant $\left(\tau_{2}\right)$ were 900 and $860 \mathrm{msec}$ for control and $\mathrm{Cm} /+$ at P13 and 820 and $920 \mathrm{msec}$ for control and $\mathrm{Cm} /+$ at P14-16, respectively.

High-voltage-activated $\mathrm{Ca}^{2+}$ peak currents and voltage dependence of steady-state activation are unaffected in $\mathrm{Cm} /+$ mutants

Finally, we investigated whether thalamic $\mathrm{HVACa}^{2+}$ currents are altered by SNAP2 5 deficiency as seen in $\mathrm{Ca}^{2+}$ channel mutants. HVA Ca ${ }^{2+}$ currents are mediated by pore-forming $\alpha_{1}$ subunits, with current amplitude and gating regulated by cytoplasmic $\beta$ subunits and transmembrane $\alpha_{2} \delta$ and $\gamma$ subunits (Ahlijanian et al., 1990; Chien et al., 1995; Witcher et al., 1995; Gurnett et al., 1996; Walker and De Waard, 1998; Meir et al., 2000; Kang et al., 2001). Our previous study demonstrated increased $\mathrm{HVA} \mathrm{Ca}^{2+}$ currents as well as altered channel kinetics in the $t g$, stg, and $l \mathrm{~h}$ absence seizure models (Zhang et al., 2002), and there is evidence that SNAP25 directly interacts with HVA Ca ${ }^{2+}$ channels (Rettig et al., 1996; Sheng et al., 1998).

Figure $6 \mathrm{~A}$ shows representative $\mathrm{HVA} \mathrm{Ca}{ }^{2+}$ current traces from wild-type and $\mathrm{Cm} /+$ mutant neurons. The $I-V$ relationships of $\mathrm{Ca}^{2+}$ currents for control and $\mathrm{Cm} /+$ mutant are shown in Figure $6 \mathrm{~B}$. Both control and mutant $\mathrm{HVA} \mathrm{Ca}^{2+}$ currents start to activate at around $-40 \mathrm{mV}$ and reach a peak between -10 and $-15 \mathrm{mV}$ (Fig. 6B). Pooled peak currents and peak current densities are shown in Figure $6 C$. The mean peak current density was $10.3 \pm 1.2$ and $11.1 \pm 1.4(\mathrm{pA} / \mathrm{pF})$ in control and $\mathrm{Cm} /+$ mutant neurons at $\mathrm{P} 13$ and $10.9 \pm 1.2$ and $10.9 \pm 0.9(\mathrm{pA} / \mathrm{pF})$ in control and $\mathrm{Cm} /+$ at $\mathrm{P} 14-16$, respectively. The mean peak amplitude was $-1198.4 \pm 219.5$ and $-1228.6 \pm 135.6(\mathrm{pA})$ in control and $\mathrm{Cm} /+$ mice at P13 and $-1149.9 \pm 217.8$ and $-1122.4 \pm 129.6$ (pA) in control and $\mathrm{Cm} /+$ mice at $\mathrm{P} 14-16$, respectively. These results show that there is no significant alteration in either peak current density or current amplitude in $\mathrm{Cm} /+$ mutants in comparison with those of wild-type mice both before the onset of SWDs and after seizure generation.

Similar to the unaltered peak current in $\mathrm{Cm} /+$, the voltage dependence of SSA for HVA $\mathrm{Ca}^{2+}$ currents in mutant TC neurons also did not shift significantly relative to that of control. The SSA curves of HVA currents in both control and mutant are demonstrated in Figure $6 D$. The mean values of $V_{1 / 2}$ and slope for SSA of HVA channels were $-20.1 \pm 1.3 \mathrm{mV}$ and $4.3 \pm 0.3$ in control and $-20.4 \pm 1.1 \mathrm{mV}$ and $3.8 \pm 0.2 \mathrm{in} \mathrm{Cm} /+$ at P13, and $-19.1 \pm 1.2 \mathrm{mV}$ and $3.7 \pm 0.2 \mathrm{in}$ control and $-18.6 \pm 1.3 \mathrm{mV}$ and $4.0 \pm 0.3$ in $\mathrm{Cm} /+$ at P14-16. The unchanged peak current density and voltage dependence of SSA differ from what we observed in $t g$, $l h$, and stg mutants (Zhang et al., 2002), which demonstrated increased peak current densities in $t g$ and $s t g$ as well as a depolarizing shift of SSA curve in $t h$ mice. Thus, the insignificant changes in HVA peak current and voltage dependence of $\mathrm{SSA}$ in $\mathrm{Cm} /+$ mice suggest that the $\mathrm{Cm} /+$ mutation does not directly or indirectly affect $\mathrm{HVA} \mathrm{Ca}^{2+}$ channel gating.

\section{Discussion}

Our results demonstrate that an increased peak current density and a depolarizing shift in the SSI of thalamic LVA Ca ${ }^{2+}$ currents coexist with frequent cortical spike-wave discharges in the dominant mouse mutant Coloboma. The LVA current elevations precede the developmental onset of the discharges, showing that they are not seizure induced, and thus provide a mechanism for the generation of the absence epilepsy phenotype in $\mathrm{Cm} /+$. The changes in HVA peak current density and voltage dependence of SSA found in $\mathrm{Ca}^{2+}$ channelopathy mutants were not present in $\mathrm{Cm} /+$, supporting the key pathogenic role of thalamic LVA $\mathrm{Ca}^{2+}$ channels in mediating neuronal hyperexcitability and epileptogenesis.

\section{Thalamic $\mathrm{Ca}^{2+}$ currents in $\mathrm{Cm} /+$ compared with calcium channel mutations \\ LVA currents}

Thalamic LVA currents are mediated by $\alpha 1 G$-I genes expressed in nonoverlapping thalamic regions (Talley et al., 1999). In a previous study of $t g$, $l h$, and stg mice, we found elevated LVA current in LDN, where the $\alpha 1 G$ gene is expressed (Zhang et al., 2002). The magnitude of the increase $(\sim 50 \%)$ in peak LVA currents in $\mathrm{Cm} /+$ is equivalent, signifying that mutations of either $\mathrm{Ca}^{2+}$ channel subunits or non-Ca ${ }^{2+}$ channel genes can lead to increased thalamic LVA currents in absence models. This finding, taken together with the report that mice lacking the $\alpha 1 \mathrm{~A}$ subunit for P/Q-type $\mathrm{Ca}^{2+}$ current also show elevated thalamic LVA cur- 
A

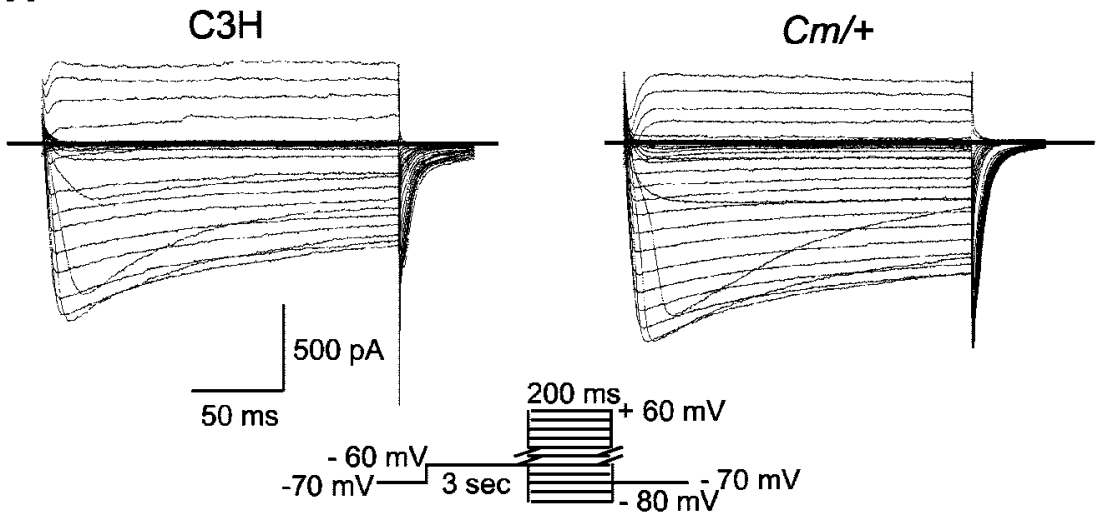

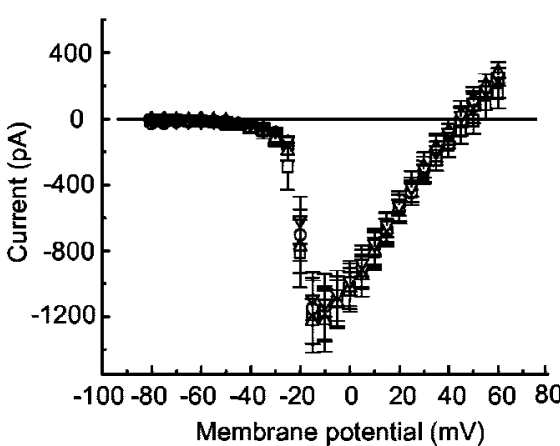

C

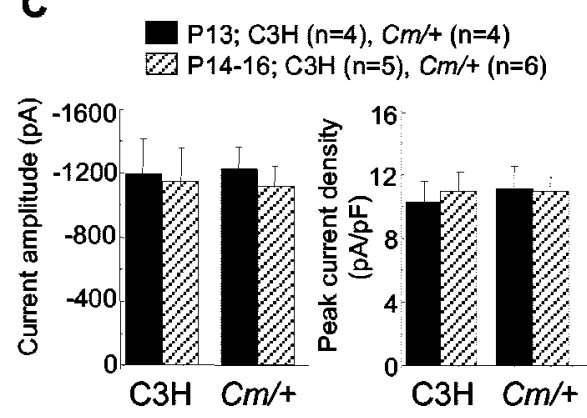

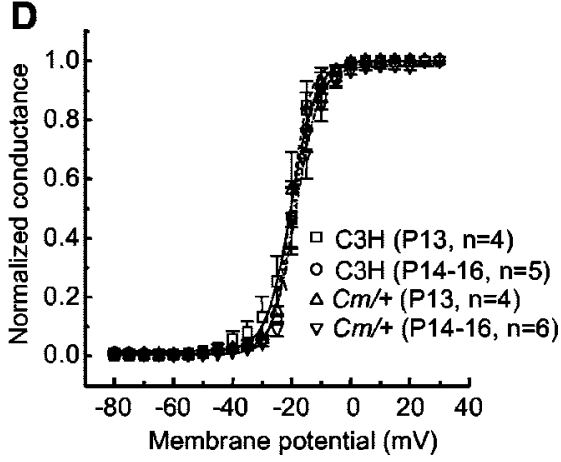

Figure 6. $\quad \mathrm{HVACa}^{2+}$ currents in $\mathrm{Cm} /+$ and wild-type mice. $A$, Representative superimposed $\mathrm{HVACa}^{2+}$ current traces from thalamic cells in control and $\mathrm{Cm} /+$ mice. The $I-V$ protocol consisted of a 3 sec prepulse potential at $-60 \mathrm{mV}$ followed by voltage steps (200 msec) ranging from -80 to $+60 \mathrm{mV}$ in $5 \mathrm{mV}$ increments, with the holding potential maintained at $-70 \mathrm{mV}$. $B$, Current density-voltage curves for HVA Ca ${ }^{2+}$ currents, constructed by plotting the normalized current amplitude at various membrane potentials. The voltage protocol used was identical to that described in A. C, Peak current density and current amplitude from B. D, SSA of HVA Ca ${ }^{2+}$ currents in control and $\mathrm{Cm} /+$. The steady-state conductance $(G)$ and voltage $(V)$ data were transformed from $I-V$ data shown in $B$. The solid and dotted curves are fits of the data to the Boltzmann equation of the form: $G / G_{\max }=1 /\left(1+\exp \left(V_{1 / 2}-V\right) / k\right)$, where $G_{\max }$ is maximum conductance, $V_{1 / 2}$ is half-maximal voltage, and $k$ is the slope.

rents and spike-wave seizures (Song et al., 2001), excludes the possibility that the potentiated LVA current arises from aberrant interactions between $\alpha 1 \mathrm{G}$ and other mutant calcium channel subunits. It is also supported by the lack of biochemical evidence for direct interactions between wild-type $\alpha 1 \mathrm{G}$ and other poreforming or regulatory $\mathrm{Ca}^{2+}$ channel subunits, except for the finding that functional expression of $\alpha 1 \mathrm{G}$ increases with coexpression of $\alpha 2 \delta$ and $\beta 1 \mathrm{~b}$ subunits (Dolphin et al., 1999). These data demonstrate that mutations of $\mathrm{Ca}^{2+}$ channel subunit genes are not required to induce the elevated LVA $\mathrm{Ca}^{2+}$ currents in thalamic neurons that are associated with SWDs.

\section{HVA currents}

In contrast, we did not observe any significant effects of reduced SNAP25 on either the peak current density or voltagedependent SSA of HVA currents in the $\mathrm{Cm} /+$ mutant. This result differs from $\mathrm{tg}$, lh, and stg mice, in which HVA peak current densities increased by $22 \%$ in $t g$ and $45 \%$ in $s t g$, and the SSA curve shifted in a depolarizing direction by $5 \mathrm{mV}$ in $\mathrm{lh}$ mice (Zhang et al., 2002). In these mutants, the altered HVA currents arise from primary genetic defects of the P/Q-type channel or lost interactions with its associated subunits (De Waard and Campbell, 1995; Letts et al., 1998; Burgess et al., 1999; Kang et al., 2001) and may also reflect the upregulation of other non-P/Q HVA channel types (Campbell and Hess, 1999). The lack of HVA current change in $\mathrm{Cm} /+$ was unexpected but may be explained by neuronal compartmentation. SNAP25 directly interacts with $\mathrm{P} / \mathrm{Q}$-type channels (Rettig et al., 1996) and is reduced in $\mathrm{Cm} /+$ mice; however, the membrane currents reported in these studies are recorded at the cell soma, and it is likely that any alteration of HVA currents in $\mathrm{Cm} /+$ neurons could be detected only at presynaptic terminals where the interaction between SNAP25 and HVA channel proteins occurs (Sheng et al., 1998; Atlas, 2001).

Potentiation of thalamic LVA Ca ${ }^{2+}$ current precedes the onset of SWDs in $\mathrm{Cm} /+$ mutants

Because potentiation of LVA currents could be activity driven, we examined thalamic LVA currents in $\mathrm{Cm} /+$ and control mice before and after the onset of seizures. At P13, a full day before even the first SWD ever appears, we found a $54 \%$ increase in peak current density of LVA $\mathrm{Ca}^{2+}$ currents, as well as an $8 \mathrm{mV}$ depolarizing shift of the inactivation curve, demonstrating that potentiation of thalamic LVA currents precedes the emergence of synchronous discharges and therefore was not seizure induced. In fact, even after several days of seizures occurring with an incidence of two to five bursts per hour, we still observed a comparable (60\%) elevation in peak current density of LVA currents together with an $8.5 \mathrm{mV}$ depolarizing shift of the voltage dependence of steady-state inactivation that was changed little from pre-seizure levels. Thus, the onset of SWDs did not add an appreciable supplemental enhancement in either LVA peak current or the shift of inactivation curve in $\mathrm{Cm} /+$. These data correspond well with other evidence that the spikewave seizure pattern, unlike that induced by convulsants (Nahm 
and Noebels, 1998), does not significantly induce gene expression patterns.

The increased thalamic LVA currents and channel availability near resting membrane potentials in the $\mathrm{Cm} /+$ mutant favor augmented burst firing and membrane hyperexcitability, because T-type $\mathrm{Ca}^{2+}$ channels begin to activate at relatively hyperpolarized membrane potentials (Huguenard and Prince, 1992; Zhang et al., 2000) attributable in part to rhythmic input from GABAergic nucleus reticularis thalami neurons. Because SNAP25 deficiency reduces transmitter release in $\mathrm{Cm} /+$ synaptosomal preparations (Raber et al., 1997), other complex changes may contribute to the altered synchronization pattern. Although we have not established a unique causal relationship between the potentiated LVA currents and seizure initiation in $\mathrm{Cm} /+$, the evidence for involvement of thalamic T-type channels in spikewave generation, as well as the exclusion of activity-dependent causes for LVA current increases in $\mathrm{Cm} /+$, suggests an important primary contribution. Interestingly, a comparable depolarizing shift of SSI with prolongation of LVA current decay has just been described in human mutations identified in human childhood absence epilepsy patients (Khosravani et al., 2004).

\section{Mechanisms for enhanced LVA current}

Several possibilities may account for elevated LVA currents in $\mathrm{Cm} /+$ mutants. First, T-type channel synthesis might increase because of impaired synaptic transmission caused by deficient SNAP25 expression or phosphorylation (Boschert et al., 1996; Genoud et al., 1999). Presynaptic release defects may lead to developmental differences in the transcriptional regulation of a heterogeneous population of T-type channel isoforms (Bertolesi et al., 2003; Yunker et al., 2003), which in turn have been shown to influence patterns of neuritogenesis during neuronal differentiation (Chemin et al., 2002). Although a minor increase in expression of $\mathrm{Ca}_{\mathrm{v}} 3.1 / \alpha 1 \mathrm{G}$ and $\mathrm{Ca}_{\mathrm{v}} 3.2 / \alpha 1 \mathrm{H}$ has been reported in adult GAERS (genetic absence epilepsy rats from Strasbourg) rats, a genetically undefined absence model (Talley et al., 2000), no alteration in the thalamic expression pattern of any of the three $\mathrm{Ca}_{\mathrm{v}} 3.1-3$ genes that closely resemble the $\mathrm{Cm} /+$ model or evidence for abnormal modulation have been detected (Zhang et al., 2002). Second, the currents may be modulated. Modulation pathways potentially responsible for increased LVA currents in $\mathrm{Cm} /+$ include the modification of T-type channels by protein kinase C (Park et al., 2003), CamKII (Welsby et al., 2003), opioid receptors (Schroeder et al., 1991), pH (Delisle and Satin, 2000; Shan et al., 2001), and anandamide (Chemin et al., 2001). It is worth noting that the Coloboma locus also contains the genes for phospholipase C (PLC) $\beta 1$ and $\beta 4$; hence $C m /+$ mice are also haploinsufficient for these enzyme isoforms. Mice with homozygous deletion of PLC $\beta 1$ show lethal tonic-clonic seizures in the second postnatal week, and $\beta 4$ mice show ataxia without seizures; however, heterozygous mice display no neurological abnormalities (Kim et al., 1997). Whether these heterozygotes show SWDs and altered LVA currents that might be related to PLC- $\beta$ signal transduction abnormalities remains to be determined.

\section{Overlapping mechanisms for absence epilepsy phenotype in Coloboma and calcium channel mutants}

The spike-wave phenotype exhibited in developing $\mathrm{Cm} /+$ mice parallels the early onset (P14-16), increasing incidence (reaching $>40$ per hour in adulthood), and ETX sensitivity of the SWDs found in $t g$, $l$, and $\operatorname{stg}$ (Noebels and Sidman, 1979; Noebels et al., 1990; Hosford et al., 1992). Interestingly, in $t g$ and stg mutants, we also observed a $50-60 \%$ increase in peak current densities and an 11-12 $\mathrm{mV}$ depolarized shift of inactivation over an age range (P8-11) before SWDs appear (data not shown). Significantly, there is additional functional overlap between epileptogenic calcium channelopathies and the SNAP25-deficient $\mathrm{Cm} /+\mathrm{mu}$ tants, because SNAP25 interacts with HVA channels involved in exocytosis, and both show transmitter release defects. We did find a difference in pharmacological sensitivity: namely, a 3.6- to 5 -fold reduction in ETX sensitivity in $\mathrm{Cm} /+$ mice compared with $\mathrm{Ca}^{2+}$ channel mutants. In $\mathrm{Cm} /+$, only a bolus dose of $5 \mathrm{mmol} / \mathrm{kg}$ (i.p.) completely blocked the occurrence of SWDs within 2-4 $\mathrm{min}$, and lower doses were ineffective, whereas in $\mathrm{Ca}^{2+}$ channel mutants, $1-1.4 \mathrm{mmol} / \mathrm{kg}$ is an effective dose (Heller et al., 1983; Aizawa et al., 1997). The blockade of SWDs by ETX could be attributable to the action of the drug on either thalamic T-type $\mathrm{Ca}^{2+}$ channels (Coulter et al., 1989) or slow inactivated $\mathrm{Na}^{+}$ currents and $\mathrm{Ca}^{2+}$-activated $\mathrm{K}^{+}$currents (Leresche et al., 1998). Future experiments will address which currents may be less sensitive to ETX in $\mathrm{Cm} /+$ neurons.

In conclusion, our results provide the first demonstration that potentiated thalamic LVA currents precede abnormal neuronal synchronization and, together with the direct effect of the $\alpha 1 \mathrm{G}$ gene on the threshold for thalamocortical SWD generation (Kim et al., 2001), provide the strongest supportive evidence so far for a major role of thalamic LVA currents in murine models of absence epilepsy. The evidence also points to developmental defects in synaptic transmission as a common cellular mechanism for the dysregulation of T-type currents that lead to this epileptic phenotype.

\section{References}

Ahlijanian MK, Westenbroek RE, Catterall WA (1990) Subunit structure and localization of dihydropyridine-sensitive calcium channels in mammalian brain, spinal cord, and retina. Neuron 6:819-832.

Aizawa M, Ito Y, Fukuda H (1997) Pharmacological profiles of generalized absence seizures in lethargic, stargazer and gamma-hydroxybutyratetreated model mice. Neurosci Res 29:17-25.

Atlas D (2001) Functional and physical coupling of voltage-sensitive calcium channels with exocytotic proteins: ramifications for the secretion mechanism. J Neurochem 77:972-985.

Barclay J, Balaguero N, Mione M, Ackerman SL, Letts VA, Brodbeck J, Canti C, Meir A, Page KM, Kusumi K, Perez-Reyes E, Lander ES, Frankel WN, Gardiner RM, Dolphin AC, Rees M (2001) Ducky mouse phenotype of epilepsy and ataxia is associated with mutations in the Cacna2d2 gene and decreased calcium channel current in cerebellar Purkinje cells. J Neurosci 21:6095-6104.

Bertolesi GE, Jollimore CA, Shi C, Elbaum L, Denovan-Wright EM, Barnes S, Kelly ME (2003) Regulation of alpha1G T-type calcium channel gene (CACNA1G) expression during neuronal differentiation. Eur J Neurosci 17:1802-1810.

Boschert U, O'Shaughnessy C, Dickinson R, Tessari M, Bendotti C, Catsicas S, Pich EM (1996) Developmental and plasticity-related differential expression of two SNAP-25 isoforms in the rat brain. J Comp Neurol 367:177-193.

Burgess DL, Jones JM, Meisler MH, Noebels JL (1997) Mutation of the $\mathrm{Ca}^{2+}$-channel $\beta$ subunit gene $C c h b 4$ is associated with ataxia and seizures in the lethargic $(l h)$ mouse. Cell 88:385-392.

Burgess DL, Biddlecome GH, McDonough SI, Diaz ME, Zilinski CA, Bean BP, Campbell KP, Noebels JL (1999) Beta subunit reshuffling modifies $\mathrm{N}$ - and $\mathrm{P} / \mathrm{Q}$-type $\mathrm{Ca}^{2+}$ channel subunit compositions in lethargic mouse brain. Mol Cell Neurosci 13:293-311.

Campbell DB, Hess EJ (1999) L-type calcium channels contribute to the tottering mouse dystonic episodes. Mol Pharmacol 55:23-31.

Chemin J, Monteil A, Perez-Reyes E, Nargeot J, Lory P (2001) Direct inhibition of T-type calcium channels by the endogenous cannabinoid anadamide. EMBO J 20:7033-7040.

Chemin J, Nargeot J, Lory P (2002) Neuronal T-type alpha1H calcium channels induce neuritogenesis and expression of high-voltage-activated calcium channels in the NG108-15 cell line. J Neurosci 22:6856-6862. 
Chien AL, Zhao X, Shirokov RE, Puri TS, Chang CF, Sun D, Rios E, Hosey MM (1995) Role of a membrane-localized $\beta$ subunit in the formation and targeting of functional L-type $\mathrm{Ca}^{2+}$ channels. J Biol Chem 270:30036-30044.

Coenen AM, Van Luijtelaar EL (2003) Genetic animal models for absence epilepsy: a review of the WAG/Rij strain of rats. Behav Genet 33:635-655.

Coulter DA, Huguenard JR, Prince DA (1989) Characterization of ethosuximide reduction of low-threshold calcium current in thalamic neurons. Ann Neurol 25:582-593.

Crunelli V, Leresche N (2002) Childhood absence epilepsy: genes, channels, neurons and networks. Nat Rev Neurosci 3:371-382.

Delisle BP, Satin J (2000) pH modulation of human T-type calcium channel gating. Biophys J 78:1895-1905.

Destexhe A, Neubig M, Ulrich D, Huguenard J (1998) Dendritic lowthreshold currents in thalamic relay cells. J Neurosci 18:3574-3588.

De Waard M, Campbell KP (1995) Subunit regulation of the neuronal $\alpha_{1 \mathrm{~A}}$ $\mathrm{Ca}^{2+}$ channel expressed in Xenopus oocytes. J Physiol (Lond) 485:619-634.

Dolphin AC, Wyatt CN, Richards J, Beattie RE, Craig P, Lee J-H, Cribbs LL, Volsen SG, Perez-Reyes E (1999) The effect of $\alpha 2-\delta$ and other accessory subunits on expression and properties of the calcium channel $\alpha 1 \mathrm{G}$. J Physiol (Lond) 519:35-45.

Dove LS, Abbott LC, Griffith WH (1998) Whole-cell and single-channel analysis of P-type calcium currents in cerebellar Purkinje cells of leaner mutant mice. J Neurosci 18:7687-7699.

Fletcher CF, Lutz CM, O’Sullivan TN, Shaughnessy JDJ, Hawkes R, Frankel WN, Copeland NG, Jenkins NA (1996) Absence epilepsy in tottering mutant mice is associated with calcium channel defects. Cell 87:607-617.

Genoud S, Pralong W, Riederer BM, Eder L, Catsicas S, Muller D (1999) Activity-dependent phosphorylation of SNAP-25 in hippocampal organotypic cultures. J Neurochem 72:1699-1706.

Gurnett CA, De Waard M, Campbell KP (1996) Dual function of the voltage-dependent $\mathrm{Ca}^{2+}$ channel alpha 2 delta subunit in current stimulation and subunit interaction. Neuron 16:431-440.

Heller AH, Dichter MA, Sidman RL (1983) Anticonvulsant sensitivity of absence seizures in the tottering mutant mouse. Epilepsia 24:25-34.

Hess EJ, Jinnah HA, Kozak CA, Wilson MC (1992) Spontaneous locomotor hyperactivity in a mouse mutant with a deletion including the SNAP gene on chromosome 2. J Neurosci 12:2865-2874.

Hess EJ, Collins KA, Copeland NG, Jenkins NA, Wilson MC (1994) Deletion map of the coloboma $(\mathrm{Cm})$ locus on mouse chromosome 2. Genomics 21:257-261.

Hess EJ, Collins KA, Wilsom MC (1996) Mouse model of hyperkinesis implicates SNAP-25 in behavioral regulation. J Neurosci 16:3104-3111.

Hosford DA, Clark S, Cao Z, Wilson Jr WA, Lin FH, Morrisett RA, Huin A (1992) The role of $\mathrm{GABA}_{\mathrm{B}}$ receptor activation in absence seizures of lethargic (lh/lh) mice. Science 257:398-401.

Huguenard JR (1996) Low-threshold calcium currents in central nervous system neurons. Annu Rev Physiol 58:329-348.

Huguenard JR, Prince DA (1992) A novel T-type current underlies prolonged $\mathrm{Ca}^{2+}$-dependent bursts in GABAergic firing neurons of rat thalamic reticular nucleus. J Neurosci 12:3804-3817.

Jouvenceau A, Eunson LH, Spauschus A, Ramesh V, Zuberi SM, Kullmann DM, Hanna MG (2001) Human epilepsy associated with dysfunction of the brain P/Q-type calcium channel. Lancet 358:801-807.

Kang MG, Chen CC, Felix R, Letts VA, Frankel WN, Mori Y, Campbell KP (2001) Biochemical and biophysical evidence for gamma 2 subunit association with neuronal voltage-activated $\mathrm{Ca}^{2+}$ channels. J Biol Chem 276:32917-32924.

Kapur A, Yeckel MF, Gray R, Johnston D (1998) L-type calcium channels are required for one form of hippocampal mossy fiber LTP. J Neurophysiol 79:2181-2190.

Khosravani H, Altier C, Simms B, Hamming KS, Snutch TP, Mezeyova J, McRory JE, Zamponi GW (2004) Gating effects of mutations in the Cav3.2 T-type calcium channel associated with childhood absence epilepsy. J Biol Chem 279:9681-9684.

Kim D, Jun KS, Lee SB, Kang NG, Min DS, Kim YH, Ryu SH, Suh PG, Shin HS (1997) Phospholipase C isozymes selectively couple to specific neurotransmitter receptors. Nature 389:290-293.

Kim D, Song I, Keum S, Lee T, Jeong MJ, Kim SS, McEnery MW, Shin HS (2001) Lack of the burst firing of thalamocortical relay neurons and re- sistance to absence seizures in mice lacking alpha(1G) T-type $\mathrm{Ca}(2+)$ channels. Neuron 31:35-45.

Lee J-H, Daud AN, Cribbs LL, Lacerda AE, Pereverzev A, Klockner U, Schneider T, Perez-Reyes E (1999) Cloning and expression of a novel member of the low-voltage-activated T-type calcium channel family. J Neurosci 19:1912-1921.

Leresche N, Rheinallt PH, Erdemli G, Guyon A, Turner JP, Williams SR, Asprodini E, Crunelli V (1998) On the action of the anti-absence drug ethosuximide in the rat and cat thalamus. J Neurosci 18:4842-4853.

Letts VA, Felix R, Biddlecome GH, Arikkath J, Mahaffey CL, Valenzuela A, Bartlett FS, Mori Y, Campbell KP, Frankel WN (1998) The mouse stargazer gene encodes a neuronal $\mathrm{Ca}^{2+}$ channel gamma subunit. Nat Genet 19:340-347.

Marescaux C, Vergnes M, Depaulis A (1992) Genetic absence epilepsy in rats from Strasbourg: a review. J Neural Transm [Suppl] 35:37-70.

McCormick DA, Contreras D (2001) On the cellular and network bases of epileptic seizures. Annu Rev Physiol 63:815-846.

Meir A, Dell DC, Stephens GL, Page KM, Dolphin AC (2000) Calcium channel beta subunit promotes voltage-dependent modulation of alpha1B by G beta gamma. Biophys J 79:731-746.

Nahm WK, Noebels JL (1998) Non-obligate role of early or sustained expression of immediate-early gene proteins c-fos, c-jun, and Zif/268 in hippocampal mossy fiber sprouting. J Neurosci 18:9245-9255.

Noebels JL (1984) A single gene error of noradrenergic axon growth synchronizes central neurones. Nature 310:409-411.

Noebels JL, Sidman RL (1979) Inherited epilepsy: spike-wave and focal motor seizures in the mutant mouse tottering. Science 204:1334-1336.

Noebels JL, Qiao X, Bronson RT, Spenser C, Davisson MT (1990) Stargazer: a new neurological mutant on chromosome 15 in the mouse with prolonged cortical seizures. Epilepsy Res 7:129-135.

Park JY, Jeong SW, Perez-Reyes E, Lee JH (2003) Modulation of Ca(v)3.2 T-type $\mathrm{Ca}^{2+}$ channels by protein kinase C. FEBS Lett 547:37-42.

Qian J, Noebels JL (2000) Presynaptic $\mathrm{Ca}^{2+}$ influx at a mouse central synapse with $\mathrm{Ca}^{2+}$ channel subunit mutations. J Neurosci 20:163-170.

Qiao X, Noebels JL (1993) Developmental analysis of hippocampal mossy fiber outgrowth in a mutant mouse with inherited spike-wave seizures. J Neurosci 13:4622-4635.

Raber J, Mehta PP, Kreifeldt M, Parsons LH, Weiss F, Bloom FE, Wilson MC (1997) Coloboma hyperactive mutant mice exhibit regional and transmitter-specific deficits in neurotransmission. J Neurochem 68:176-186.

Rettig J, Sheng ZH, Kim DK, Hodson CD, Snutch TP, Catterall WA (1996) Isoform-specific interaction of the $\alpha 1 \mathrm{~A}$ subunits of the brain $\mathrm{Ca}^{2+}$ channels with the presynaptic proteins syntaxin and SNAP-25. Proc Natl Acad Sci USA 93:7363-7368.

Schroeder JE, Fischbach PS, Zheng D, McCleskey EW (1991) Activation of $\mathrm{mu}$ opioid receptors inhibits transient high- and low-threshold $\mathrm{Ca}^{2+}$ currents, but spares a sustained current. Neuron 6:13-20.

Shan MJ, Meis S, Munsch T, Pape HC (2001) Modulation by extracellular $\mathrm{pH}$ of low- and high-voltage-activated calcium currents of rat thalamic relay neurons. J Neurophysiol 85:1051-1058.

Sheng ZH, Westenbroek RE, Catterall WA (1998) Physical link and functional coupling of presynaptic calcium channels and the synaptic vesicle docking/fusion machinery. J Bioenerg Biomembr 30:335-345.

Song I, Kim D, Jun K, Shin HS (2001) Role of T-type calcium channels in the genesis of absence seizure in the mutant mice for $\alpha_{1 \mathrm{~A}}$, the pore-forming subunit of the P/Q-type calcium channel. Soc Neurosci Abstr 27:151.21.

Sorensen JB, Nagy G, Varoqueaux F, Nehring RB, Brose N, Wilson MC, Neher E (2003) Differential control of the releasable vesicle pools by SNAP-25 splice variants and SNAP-23. Cell 114:75-86.

Talley EM, Cribbs LL, Lee JH, Daud A, Perez-Reyes E, Bayliss DA (1999) Differential distribution of three members of a gene family encoding lowvoltage-activated (T-type) calcium channels. J Neurosci 19:1895-1911.

Talley EM, Solorzano G, Depaulis A, Perez-Reyes E, Bayliss DA (2000) Lowvoltage-activated calcium channel subunit expression in a genetic model of absence epilepsy in the rat. Mol Brain Res 75:159-165.

Wakamori M, Yamazaki K, Matsunodaira H, Teramoto T, Tanaka I, Niidome T, Sawada K, Nishizawa Y, Sekiguchi N, Mori E, Mori Y, Imoto K (1998) Single tottering mutations responsible for the neuropathic phenotype of the P-type calcium channel. J Biol Chem 273:34857-34867.

Walker D, De Waard M (1998) Subunit interaction sites in voltagedependent $\mathrm{Ca}^{2+}$ channels: role in channel function. Trends Neurosci 21:148-154. 
Washbourne P, Thompson PM, Carta M, Costa ET, Mathews JR, LopezBendito G, Molnar Z, Becher MW, Valenzuela CF, Partridge LD, Wilson MC (2002) Genetic ablation of the t-SNARE SNAP-25 distinguishes mechanisms of neuroexocytosis. Nat Neurosci 5:19-26.

Welsby PJ, Wang H, Wolfe JT, Colbran RJ, Johnson ML, Barrett PQ (2003) A mechanism for the direct regulation of T-type calcium channels by $\mathrm{Ca}^{2+} /$ calmodulin-dependent and kinase II. J Neurosci 23:10116-10121.

Wilson MC (2000) Coloboma mouse mutant as an animal model of hyperkinesis and attention deficit hyperactivity disorder. Neurosci Biobehav Rev 24:51-57.

Witcher DR, De Waard M, Liu H, Pragnell M, Campbell KP (1995) Association of native $\beta \mathrm{Ca}^{2+}$ channel subunits with the $\alpha 1$ subunit interaction domain. J Biol Chem 270:18088-18093.
Yunker AMR, Sharp AH, Sundarraj S, Ranganathan V, Copeland TD, McEnery MW (2003) Immunological characterization of T-type voltagedependent calcium channel $\mathrm{Ca}_{\mathrm{v}} 3.1$ (alpha1G) and $\mathrm{Ca}_{\mathrm{v}} 3.3$ (Alpha1I) isoforms reveal differences in their localization, expression, and neural development. Neuroscience 117:321-335.

Zhang Y, Cribbs LL, Satin J (2000) Arachidonic acid modulation of $\alpha 1 \mathrm{H}$, a cloned human T-type calcium channel. Am J Physiol 278:H184-H193.

Zhang Y, Mori M, Burgess DL, Noebels JL (2002) Mutations in highvoltage-activated calcium channel genes stimulate low-voltage-activated currents in mouse thalamic relay neurons. J Neurosci 22:6362-6371.

Zwingman TA, Neumann PE, Noebels JL, Herrup K (2001) Rocker is a new variant of the voltage-dependent calcium channel gene Cacnala. J Neurosci 21:1169-1178. 